\title{
ВЛИЯНИЕ ДЕМОНСТРАЦИОННЫХ ЭФФЕКТОВ НА СТАНОВЛЕНИЕ ПОЛИТИЧЕСКИХ ИНСТИТУТОВ
}

\begin{abstract}
Аннотация. В статье представлен подход к анализу динамики политических институтов в России через призму воздействия демонстрационных эффектов. Объектом исследования является политический процесс в незападных обществах. Предмет исследования - развитие политических институтов в России. Опираясь на сложившиеся в отечественной и зарубежной политической науке подходы, автор исследует возможности политических трансформаций в сравнительной перспективе. Цель работы - выявление особенностей воздействия демонстрационных эффектов. В работе выделены основные проблемы совершенствования институционального дизайна политических систем в условиях глобальных коммуникации и распространения представлений о современном опыте организации и функционировании публичной власти. Методологической основой исследования является системный, структурно-функциональный, сравнительно-политический подходы, методы анализа, синтеза, индукции, дедукции, наблюдения. В исследовании указывается на необходимость серьезного изучения возможностей и ограничений универсалистского подхода к "продвижению демократии». С учетом опыта современного "постконфликтного регулирования» в ряде государств мира делается вывод о необходимости взвешенной оценки собственного опыта развития политических институтов, обеспечения устойчивой государственности и политической ответственности власти.
\end{abstract}

Ключевые слова: геополитика, глобальное информационное пространство, мировая политика, внешняя политика США, международные отношения, дипломатия, интересы, государство, безопасность, США.

Review: The paper presents an approach to the analysis of the dynamics of political institutions in Russia through the prism of the impact of demonstration effects. The object of the research is political process in non-Western societies. The subject of the research is the development of political institutions in Russia. On the base of the approaches, prevailing in the domestic and foreign political science, the author examines the possibility of political change in the comparative perspective. The purpose is to reveal the characteristics of the impact of demonstration effects. The author outlines the basic problems of the improvement of the institutional design of political systems in the context of global communication and dissemination of ideas about the contemporary experience of the organization and functioning of public authority. The methodology of the study is based on the systems approach, the structural-functional and comparative-political approaches, the methods of analysis, synthesis, induction, deduction and observation.The author points at the need for a serious study of the possibilities and limitations of the universalist approach to "democracy promotion." Taking into account the experience of the contemporary "post-conflict regulation" in a number of countries in the world, the author concludes about the need for a balanced assessment of the native experience of political institutions, the provision of the sustainable statehood and political responsibility of the authority.

Keywords: interests, geopolitics, global information space, world politics, U.S. foreign policy, international relations, diplomacy, state, security, USA.

$\mathrm{B}$ современной политической науке вопросы, касающиеся природы и функционирования институтов, остаются весьма дискуссионными. Одним из наиболее ярких проявлений этого представляется та интересная и весьма насыщенная разнообразием позиций и оценок дискуссия, которая связана с обсуждением влияния того или иного варианта институционального дизайна на становление демократического режима в стране. Здесь часто можно заметить, как выстраивается аргументация сторонников и противников парламентской и президентской формы правления в республиках (включая государства, в которых относительно недавно произошла смена формы правления); дебатируются возможности/ограничения той или иной избирательной системы и формата партийной системы и др. В целом, можно отметить значительное превалирование конструктивистской методологической парадигмы, в рамках которой выделяются конкретные политические подходы и инструменты для формирования новых институциональных форм в тех государствах, которые «переходят к демократии». В рамках данной публикации хотелось бы сосредоточиться на одном интересном аспекте институциональных изменений: влиянии т.н. демонстрационных эффектов на трансформацию политических институтов.

В отечественной политологической литературе упоминания об этих эффектах встречаются не часто и в различном контексте. Можно выделить работы одного из ведущих отечественных политологов, профессора МГУ А.И. Соловьева, который 
указывает на необходимость учета феномена демонстрационных эффектов при анализе политических процессов в обществах, переживающих смену парадигм развития [43, С. 71-84, 44, С. 64-76]. В этих публикациях ставится вопрос о возможных границах влияния таких эффектов на принятие решений в условиях трансформации политических систем, а также о масштабах воздействия на внутреннюю политику государств тех особенных референтных образцов поведения, которые активно продвигаются мощными государствами и иными центрами влияния на международной арене. В работах известного российского теоретика мировой политики и международных отношений, профессора МГУ П.А. Цыганкова большое внимание уделено МДЭ («международным демонстрационным эффектам») $[49,50]$. Данный подход выделяет необходимость учета интенсивного стихийного и целенаправленного воздействия на характер отношений в мировой политике новых глобальных тенденций. При этом в центре внимания оказывается один из самых важных вопросов: кто именно будет определять содержание и характер международных отношений в обозримом и более отдаленном будущем - государство, международные организации или «параллельные участники» («акторы вне суверенитета»)? Рискнем предположить, что одним из проявлений демонстрационного эффекта уже непосредственно в политической науке можно считать полемику о ТДМ («теории демократического мира»). Представляется весьма интересной критика позиций некоторых отечественных авторов в статье П.А. и А.П. Цыганковых: «Сознательно или полусознательно, искренне романтически или только расчетливо, но приверженцы ТДМ приглашают Россию обеспечить себе мирное будущее и надежную безопасность «самым простым, ясным» способом - посредством скорейшего превращения в зрелую демократию и окружения себя такими же зрелыми демократиями как минимум по всему периметру российских границ». (Цит. по: Цыганков П.А., Цыганков А.П. Кризис идеи «демократического мира».// Международные процессы. 2005 Том 3. № 3(9). Сентябрь-декабрь).

Демонстрационный эффект обычно определяют через воздействие на сознание и поведение отдельных индивидов и социальных групп какихлибо образцов жизнедеятельности, представляющих хозяйственный уклад, социальные стандарты и стили потребления иных, более высоких статусно и привлекательных для подражания социальных страт. Таково, например, одно из определений экономистов: «Демонстрационный эффект - воздействие уровня жизни одной социальной группы на структуру спроса и экономическое поведение другой группы. Проявляется в форме возникнове- ния новых потребностей и затрагивает лишь наиболее выразительные элементы потребления, такие, как автомобиль, дача, шуба и т. п. Является одним из наиболее мощных стимулов массового потребления, поскольку отдельные социальные группы стремятся приблизить свой образ жизни, по крайней мере внешне, к образу жизни групп с более высокими доходами» (Цит. по: Райзберг Б.А., Лозовский Л.Ш., Стародубцева Е.Б. Современный экономический словарь. 5-е изд., перераб. и доп. М., 2007). Однако, стоит отметить, что такой эффект проявляется как ощущение новых потребностей, но не затрагивает все составляющие потребления. В основном это касается внешних, наиболее выразительных аспектов потребления, позволяющих вызывать чувства сопричастности, социального роста и самореализации через потребление. В современных развитых государствах демонстрационный эффект позволяет мощно стимулировать процесс массового потребления, создавать и поддерживать социальную иерархию через формирование отдельных социальных групп, соответствующим образом ориентированных на доминирующие модели поведения (технологии маркетинга и рекламы: сегментирование рынка, таргетирование целевых групп, расчет траектории «жизненного цикла товара» и выделение особенностей УТП «уникального товарного предложения» и т.д.).

В работе американского профессора Т.Р. Гарра, посвященной анализу причин и характера протекания внутриполитической гражданской борьбы, дается такое определение: «... показ результатов модернизации увеличивает экспектации благ, благ развития личности, удовольствий урбанистической социальной жизни. Демонстрационный эффект действует также в отношении ценностей власти» [30, С. 147]. В исследовании Т.Г. Гарра указывается на то, что демонстрация иного «человеческого материала» и иной культуры сама по себе может и не вызывать возрастания неудовлетворенности и склонности к политическому насилию для его преодоления в обществе. Однако, при определенных условиях, которые в данном исследовании сформулированы в виде двух гипотез, такое вполне возможно.

Для нашей темы представляется важным констатировать, что демонстрационные эффекты имеют не только массовый социальный характер, но прямо воздействуют на власть, ее носителей политические элиты и лидеров. В значительной степени эти эффекты трансформируют представления правящего класса об обществе, о политических стратегиях, наконец, о своей собственной роли в политическом процессе. Иначе говоря, можно предположить, что пришедшие к власти могут под влиянием внешних факторов изменить или се- 
рьезно скорректировать свои первоначальные политические стремления и даже модифицировать собственную картину мира. Во многом это связано с логикой политического процесса на его различных стадиях: одно дело бороться за завоевание власти, другое - стремиться ее удержать. Но, кроме этого, по-видимому, имеются и иные причины. Среди них - увеличение информационной насыщенности той среды, в которой живет и работает политик. Не секрет, что на первых порах многие политические лидеры испытывают серьезные затруднения в получении адекватной социально-политической информации, да и просто еще не имеют достаточного опыта работы с большими объемами данных и, зачастую, вынуждены полагаться на мнения своих советников, экспертов. В то же время, когда наступает время принятия политических решений, приходится идти наперекор экспертному мнению, иногда - вопреки мнению большинства граждан. Как правило, важнейшим вопросом в таком случае становится способность политика к эффективной коммуникации, использованию всего арсенала методов и технологий обеспечения понимания гражданами или хотя бы эмоциональной поддержки.

Влияние демонстрационных эффектов на становление новых политических институтов в России, на наш взгляд, усилилось после завершения «холодной войны». Связано это было с тем, что на смену приоритетам, декларировавшимся коммунистической партией, пришли такие концепты как «разделение властей», «правовое государство», «гражданское общество» и др. По форме это было скорее идеологическое замещение, служившее средством мобилизации новой политической элиты. По существу - скорее одно из следствий резкого изменения информационных потоков (ослабление советской идеологической пропаганды внутри СССР и практически обрушение системы работы по «проецированию силы» вовне). Кроме того, в условиях, когда была утрачена поддержка гражданами декларируемых коммунистической партией целей и приоритетов, сформировался относительно новый политический язык. Создание новых институтов власти происходило одновременно с разрушением прежних структур и политических институтов. Одним из основных принципов являлось отрицание советского опыта политического и государственного строительства и особое внимание к политическим институтам «развитых демократических стран», выступавших в роли эталона или примера для подражания. Политическая пропаганда и манипуляции общественным сознанием приводили к тому, что общество оказалось постепенно подготовлено психологически к смене идеологических ориентиров: на фоне «краха» коммунистического проекта новые ценности («общечеловеческие»), «подлинно демократические» стали рассматриваться как «настоящие», предписывающие «возвращение» страны Советов в общее русло мирового прогресса.

Происходившие в начале 1990-х гг. в нашей стране реформы политической системы нашли свое отражение в новом законодательстве о выборах, политических партиях, местном самоуправлении, приватизации и т.д. Наиболее масштабные изменения коснулись Конституции России. Само принятие Основного закона стало драматичным конфликтным этапом политического процесса в России. В конечном итоге возникли весьма своеобразные институциональные гибриды - новый парламент, институт президентства, Конституционный Суд и др., - которые созданы якобы в подражание западным образцам, где-то имитируют их деятельность, но в действительности функционируют по-советски, сочетая новую повестку дня с поведенческими стереотипами партийного руководства политическим процессом.

Примером проявления демонстрационного эффекта может служить следующее. На ранних стадиях подготовки конституции России (1991 1993 гг.) парламентская Конституционная Комиссия проявляла особый интерес не только к Конституции США, но и к конституциям ряда штатов, включая конституции Иллинойса, Охлакомы и Нью-Хемпшира. Наивысшего уровня американское влияние достигло в начале 1993 г., когда руководство российской Конституционной Комиссии встретилось с экспертами по Конституции Соединенных Штатов на продолжавшейся неделю конференции в Вашингтоне. Естественно, что видные американские правоведы, судьи, законодатели в своих выступлениях высказывали массу критических замечаний по тогдашнему проекту российской Конституции, сделанные с ограниченных американским видением проблемы позиций.

Использование сложившегося образа демократической страны на сегодня стало уже привычной политической технологией администраций президентов США. Она позволяет решать целый ряд важных задач при конструировании и репрезентации в системе массовых коммуникаций тех или иных составляющих этого имиджа: укрепление политического влияния, преференции для бизнеса, продвижение национальных интересов в целом. Однако, как показывают исследования, в политической науке и сравнительном государствоведении неоднократно ставился вопрос о влиянии именно американской версии дизайна политических институтов на развитие так называемых «новых демократий». Как правило, его рассматривали сквозь призму особенностей реализации президентской республики как формы правления. Сложилось мнение, 
что возможности использования американского конституционного и политического опыта весьма ограниченные, особенно в части реализации принципа разделения властей и «сдержек и противовесов» [1, Р. 310-340]. Исследователи отмечают, что в США помимо уникального исторического опыта функционирования демократии существуют и так называемые «параконституционные основания», выражающиеся в опоре на ценности либеральной демократии и поддержании духа свободы как главной идеологии мира. Отечественные авторы видят корни стабильности американской политической системы в особом положении законодательной власти: «Не исключено, что стабильность президентской системы США обусловлена уникальной законодательной структурой, составляющей сердцевину этой системы. Некоторые специфические качества Конгресса позволяют американской политической системе избегать нестабильности, которая присуща другим президентским системам. Более того, Конгресс может содействовать укреплению политической стабильности посредством сдерживания сил, требующих изменений, путем поощрения политической “отзывчивости" и расширения подотчетности исполнительной ветви власти, да и сам Конгресс может проявлять “отзывчивость" хотя бы чисто символически. Устойчивая стабильность президентской системы США вопреки частым тупиковым ситуациям является продуктом политической среды, характеризующейся, как и во времена после ратификации Конституции, слабым политическим участием и умеренными политическими требованиями» [37, С. 530] .

Наряду с проекцией собственного опыта и институциональных решений на другие страны, развивающиеся в иных социокультурных и исторических традициях взаимодействия власти и общества, современные государства могут активно воздействовать на становление институтов в период конфликтов и гражданских войн.

Особый интерес представляет отдельное направление в западной политической науке, которое рассматривает не только возможности использования, но и конкретные формы воплощения западных политических и правовых институтов в тех странах, которые сравнительно недавно пережили гражданскую войну или встали на путь «переучреждения» государственности. Так, например, в работе Кристи Самуэльса «Строительство государства и конституционный дизайн после конфликта» на примере нескольких государств, послуживших объектами исследования в рамках всего научного проекта «State-building Program», выполненного International Peace Academy (IPA), - Босния и Герцеговина, Фиджи, Ливан, Северная Ирландия, ЮАР и Уганда $[22,23]$. В данном случае рассматри- ваются конкретные формы разделения властей и модели сдержек и противовесов, закрепление которых в конституции могло бы, по мнению автора, стабилизировать политический процесс. Кроме того, анализируются возможности реализации оптимальных моделей избирательного процесса. Проекция этого опыта на «пост-конфликтные» Ирак и Афганистан заявляется как один из возможных практических ракурсов дальнейшего исследования проблемы. Аналогичный подход реализован в большой программной статье в «Гарвардском правовом обозрении». Здесь рассматривается сложный процесс взаимодействия контртеррористических (военных и специальных полицейских) операций и действий по формированию новой администрации, нового политического режима в целом [4, Р. 1622-1643]. Вообще в американской политологии есть устойчивое научное мнение о необходимости изучения роли США в становлении наций-государств, использовании институтов поддержки демократии, формировании современных конституционных и политических систем $[7,8]$. В обширной монографии, выпущенной под эгидой корпорации РЭНД предметно рассматриваются основные этапы и особенности государственного строительства в условиях после силового «демонтажа» предыдущего режима. Особое внимание уделяется конструированию современных политических институтов и «демократизации» как единственному средству «оставить общество в мире с самим собой и своими соседями». Общий смысл этого «руководства по строительству наций» сводится к последовательности действий и поддержке местных инициатив по развитию демократии и самоуправления в рамках современного понимания эффективности политических институтов.

Весьма интересный подход к конструированию институтов демонстрирует известный политолог Эндрю Рейнолдс. В своей статье о «конституционной медицине» (что по смыслу в более четком переводе может звучать как «лечение посредством конституции») он исследует так называемую конституционную инженерию в постконфликтных ситуациях (в Афганистане, Ираке и Судане) [21, Р. 54-68]. Его подход к изучению возможностей демократического дизайна для урегулирования конфликтов в хрупких и разделенных обществах базируется на возможности использования медицинской практики диагностики и лечения сложных заболеваний. Рейнолдс утверждает, что разработка конституции для стабилизации государства очень похожа на лечение больного и имеет, по сути, схожие этапы (весь медицинской цикл от сортировки больных по соответствующим отделениям и оказания экстренной медицинской помощи до планомерного лечения и долгосрочного поддер- 
жания здоровья). В этом контексте «трансплантация институтов» выглядит как реальная возможность замены функциональных механизмов общественно-политического управления в случае «неизлечимости» имеющихся или их стойкой дисфункции. В этой связи автор указывает на необходимость учитывать различные этапы демократического развития государства и общества с тем, чтобы адаптировать политические институты к насущным потребностям. Весьма интересен тезис о том, что в конституции все институты должны быть соответствующим образом совмещены, чтобы не вызывать «отторжения» и дать «пациенту» стабилизироваться, «выздороветь», развивая демократию. На наш взгляд, такой подход красноречиво отражает стремление некоторых западных государств активно участвовать в формировании лояльных и подконтрольных политических режимов в большей степени, чем заботиться о становлении действительно эффективного национального государства в том или ином регионе политической нестабильности.

По-видимому, понимая всю остроту проблемы «продвижения демократии» в мире и ответственности США за этот процесс, известный американский политолог Томас Карозерс выпустил работу с подведением итогов разрушительной политике Дж. Буша-младшего [3]. По мнению этого автора, для новой администрации являются актуальными вопросы восстановления доверия к демократии вообще и к США как «промоутеру» (в данном контексте это понятие можно перевести по аналогии с использованием его в шоу-бизнесе как «продвигающий» или «раскручивающий») этого процесса [3, P. 19-20]. Однако, как отмечает Т. Карозерс, данный призыв не должен быть идеалистичным, поскольку, оставаясь верными самой демократии как глобальной идее, американцы должны понимать, что ее распространение в рамках т.н. «третьей волны» - лишь эпизод истории. Это состояние характеризовалось следующими признаками:

- демократизация являлась естественным процессом, этот импульс распространялся по всему миру в силу основных структурных факторов (экономический рост и распространение политической свободы);

- не было существенных конкурентов западной либеральной демократии, никакой другой политической идеологии или типа политической системы, претендующей на мировое влияние;

- рыночные реформы стимулировали динамику мировой экономики, содействовали глобальной демократизации;

- сама глобализация воспринималась и являлась по сути скорее вестернизацией, что также способствовало распространению демократии;
- Соединенные Штаты являются естественным лидером или, по крайней мере, играют преобладающую роль в продвижении демократии.

В настоящее время эти постулаты уже не работают, заметны иные тенденции, которые необходимо учитывать:

- $\quad$ количественный рост демократий замедлился (по данным изучения так называемых «электоральных демократий», то есть всех, где проходят выборы, пусть даже и номинальные);

- $\quad$ остро стоит вопрос консолидации демократии в нестабильных режимах и нет уверенности в том, что количество случаев демократических завоеваний перевесит число авторитарных трансформаций;

- экономическое развитие Китая и России, где существуют недемократические режимы, может проецироваться на другие регионы мира, Центральную Азию, Ближний Восток, формировать соответствующие ориентиры у национальных элит и ожидания граждан;

- $\quad$ высокие цены на нефть и газ в совокупности с разочарованием населения многих государств от либеральных экономических реформ препятствуют дальнейшей демократизации;

- процесс глобализации уже не связывается только с распространением западных социальных и политических ценностей, а авторитарные режимы с успехом научились имитировать западные усилия по распространению демократии.

Последний тезис обращает внимание на то, что американское лидерство в процессе «продвижения демократии» оспаривается как раз теми государствами, которые в обозримой перспективе будут считаться (исходя из реалистического подхода) наиболее вероятными соперниками США - Китай и Россия. Все это заставляет американцев искать более гибкие и менее разрушительные средства для восстановления роли своей державы в мире, придания позитивного образа политике США. Именно в этом контексте звучат призывы Т. Карозерса обратить внимание на состояние демократии внутри США, прислушаться к предложениям ряда правозащитных организаций («Хьюман райтс уотч» и Американского Союза гражданских свобод). Среди необходимых мер могут быть: запрет пыток в законодательстве и практике, закрытие секретных тюрем ЦРУ (конкретно - тюрьмы Гуантанамо), запрет чрезвычайной выдачи, ужесточение определения «вражеского комбатанта» и др. В конечном итоге такой подход, по мнению автора, сможет изменить сложившийся силовой стиль американской политики и негативный имидж страны-агрессора.

Заимствование политических и правовых институтов США стало достаточно типичным вслед- 
ствие процессов глобализации, как пишет известный российский правовед В.И. Лафитский. ОН отмечает, что, как правило, не инкорпорация норм международного права является главным инструментом воздействия глобализации на конституционный строй, а, скорее, «заимствование или рецепция конституционных моделей других государств» [34, С. 311]. При этом заимствуются не только базовые принципы конституционного строя: верховенство права, разделение властей, федерализм, но и частные решения по организации власти и регулированию экономических отношений. Именно то, что касается экономики представляет особый интерес, поскольку здесь, в сфере регулирования экономического развития, решения глобальных задач по распространению влияния американских корпораций, открытия новых товарных, сырьевых и финансовых рынков лежат основные интересы по «продвижению» и «содействию демократии». К этому комплексу условий обычно добавляют старый тезис о том, что демократии «не воюют друг с другом», что, по-видимому, должно являться обоснованием соответствующих стратегий в сфере глобальной и региональной безопасности.

В работе известного американского политолога, специалиста по транзитам, профессора Стэндфордского университета и сотрудника Национального фонда за демократию (National Endowment for Democracy) Лари Даймонда делается особый упор на то, что продвижение «демократии» в постконфликтных государствах (для примера в статье отмечаются помимо Ирака, Босния и Герцеговина, Ангола) не является изначально ущербным делом. Наоборот, автор уверен, что внимательный учет местных социокультурных особенностей, этнического и религиозного факторов и координация усилий с международными организациями (главным образом ООН) способны в длительной исторической перспективе принести важные результаты. Особое внимание уделяется деятельности по подготовке и проведению свободных общенациональных выборов, формированию коалиций поддержки демократических реформ на базе некоммерческих гражданских организаций и т.д. [6, Р. 93-116] Опыт такого «урегулирования» в Ираке сделал такой анализ более осторожным, но не снял самой парадигмы «содействия демократии» с повестки дня [5, Р. 9-23]. Все это в целом отражает типичный подход не только для американской политической доктрины «продвижения демократии», но и достаточно определенный научный ракурс. Последний выражается в том, что «промоутеры» демократии исходят из собственного представления о дальнейшей политической и социально-экономической перспективе развития той или иной страны, тем самым фактически серьезно упрощая сложную ситуацию после гражданской войны или оккупации.

Внимательно относиться к институциональным заимствованиям призывал известный американский политолог Питер Ордешук. Указывая на опыт принятия российской Конституции 1993 г., он обозначил существование проблемы ее эффективности в связи с ограничением возможностей учета мнения большинства политических акторов и появления на политической арене фактора силы и прямого давления [18, Р. 55-72].

Европейские авторы, обращавшиеся к проблеме институционального переноса, отмечают: «институциональная трансплантация включает в себя сознательное стремление изменить существующие институты и заменить или дополнить их новыми институтами, заимствованными из других стран или из другого контекста» [24, Р. 283]. В данном определении присутствует фиксация рационального подхода к новациям в сфере институтов, что позволяет оперировать в изучении специфики этого процесса понятиями интересов и стратегий политических акторов, производить расчеты возможных выгод и издержек конкретных институциональных решений. В работе Джона Элстера, Клауса Оффе и Ульриха Пройса рассматривается проблема институционального дизайна в контексте посткоммунистических трансформаций в Восточной Европе [9]. Авторы указывают на особую сложность процесса трансформации политических институтов в связи с тем, что перед этими государствами стояла тройная задача «перехода» (от авторитаризма к демократии, от плановой социалистической экономики к либеральному рынку, и от автаркического социально-экономического существования к интеграции в мировую экономику). Именно поэтому построение нового государства и общества, по меткому выражению Клауса Оффе, выглядит как «перестройка корабля в открытом море».

Масштаб и неоднозначность институциональных изменений в постсоциалистических государствах связаны с тем, что решение указанных задач «перехода» происходит одновременно и порождает значительные противоречия. Формирование рыночной экономики и демократической политической системы сопряжено с учреждением новой социальной группы - предпринимателей, бизнесменов. По мнению К. Оффе, рынок способствует развитию демократии, а не демократия - созданию рынка. Кроме того, как известно, в целом ряде государств развитые рыночные отношения не привели до сих пор к становлению полноценного демократического общества (Китай, Тайвань, Сингапур, Южная Корея). В этих странах оформились различные разновидности авторитарных режимов, которые относительно стабильны [39]. Таким образом, развитое рыночное общество лишь до определенной степени формиру- 
ет условия для того, чтобы демократия стала оптимальным способом согласования интересов и достижения консенсуса.

Клаус Оффе данную дилемму формулирует так: «правовая и представительная политическая система станет адекватной и воспроизводящей легитимность только тогда, когда уже достигнута определенная ступень автономного экономического развития» $[39$, С. 11]. Так, экономическая система, которая возникает в постсоциалистических странах, получает у К.Оффе наименование «политический капитализм». Этот вариант капитализма насаждается реформаторской элитой, в отличие от аутентичного западного образца, движущим мотивом которого становится заинтересованность всего общества в эффективном экономическом механизме. Многочисленные проблемы, связанные с социальными издержками монетаристских технологий экономических реформ, создают серьезные трудности для поддержки и легитимации преобразований. Таким образом, в случае, если ни демократия, ни рынок не будут желаемыми для большинства населения, то, по выражению К. Оффе, «мы имеем дело с “ящиком Пандоры”, полным парадоксов, перед которыми капитулирует любая “теория” перехода» [39, С. 15]. Необратимость демократического развития будет гарантирована при условии, что вынужденные приспосабливаться к новому социально-экономическому положению граждане имеют достаточный запас терпения и оптимизма, для того чтобы наконец дождаться позитивных итогов преобразований. При этом их уверенность в правильности избранного политическим классом вектора будет в какой-то мере зависеть и от того, как подается в общественное сознание импорт институтов, «трансплантация» или заимствования.

Важный вопрос, касающийся природы «перемещения» институтов - источники заимствований, исходные образцы. Таковыми выступают, как правило, политические институты и практики современных демократий, которые демонстрируют высокие темпы экономического развития и серьезный уровень обеспечения социальных стандартов. В данном случае представляется актуальным подход, который позволяет зафиксировать, что именно принимается за некую точку отсчета при реализации институциональных новаций. А. Олейник выделяет три источника импорта формальных институтов [38, С. 202-204]:

1) из какой-либо теоретической модели («импорт из идеи»). В данном случае речь идет не столько об импорте самих институтов, сколько о попытке политической импровизации на основе теоретических посылов - здесь важную роль играет идеологическое обеспечение институционального строительства (политический класс, ЛПР навязывают обществу соответствующую парадигму движения к «правильно устроенному социуму», по версии «классиков»). Американо-канадский экономист, антрополог и социолог, один из основоположников экономической антропологии Карл Поланьи описал типичный случай создания формальных институтов. По его мнению, институты свободной рыночной конкуренции никогда не смогли бы возникнуть сами по себе, без целенаправленных усилий со стороны законодателей. Действительно, рыночная экономика на Западе развивалась путем естественного складывания локальных рынков, действовавших на основе неформальных норм персонифицированного доверия. Свободная рыночная экономика, теоретически описанная в работах А. Смита, И. Бентама и др., предполагает деперсонифицированные, универсальные взаимодействия. Трансакционные издержки при этом настолько велики, что такое взаимодействие попросту невозможно без наличия формальных институтов. Эти институты и «создали», опираясь на теоретическую модель А. Смита («каким должен быть рынок»), британские парламентарии в XIX в. [36, С. 11];

2) формальные институты могут создаваться по образцам, когда-то существовавшим в истории страны, но затем исчезнувшим («импорт из прошлого»). В качестве примеров можно привести Германию, где в Средние века по образцу Рима были созданы институты «Священной Римской империи», а в годы нацизма и в риторике, и в символике широко использовалось «великое историческое прошлое» немецкого народа, прежде всего времен «первого рейха». Успешным опытом заимствования из прошлого стала реставрация монархии в пост-франкистской Испании на основе «пакта Монклоа». В современной России такой ракурс институциональной инновации под «влиянием истории» можно использовать при анализе возникновения института Государственного совета РФ. По мнению Л.А. Петручак, современный «процесс реформирования судебной системы Российской Федерации происходит под знаком возвращения в судоустройство демократических принципов и институтов судебных уставов Александра II. Примером тому может служить введение сегодня в России суда присяжных и мировой юстиции. Обращение юристов к отечественной правовой традиции призвано противостоять ярко выраженной в современном российском праве тенденции заимствования западных правовых ценностей и институтов» $[40$, С. 6$]$; 
3) создаваемые формальные институты могут строиться по образцам, существующим в других странах (импорт в буквальном смысле этого слова). Если первые два варианта используются не часто, то импорт иностранных институтов - типичное явление в мировой истории. Ярким примером могут служить в данном случае Конституции Японии и Германии, принятые после поражения милитаристского и национал-социалистского режимов во Второй мировой войне соответственно в 1946 и 1949 гг. При всех серьезных различиях в данных актах, фиксирующих новые рамки политической системы, оба эти документа объединяет важное качество - англосаксонская правовая система (в ее американской версии) оказала существенное влияние на японский и германский конституционализм, вступив в противоречие с прежней правовой традицией этих стран. Формальные политические институты, основной закон (Grundgesetz) в Западной Германии разрабатывались самой политической элитой, но под жестким внешним контролем [12] (От понятия конституция (нем. - Verfassung) было решено временно отказаться по решению Парламентского совета, на который были возложены функции Конституционной Ассамблеи Западной Германии, под руководством К. Аденауэра с вполне определенной целью. Основной закон рассматривался как переходный документ, принятый для управления частью Германии до того момента, когда свободное решение немецкого народа восстановит единство страны. Когда наступил этот день 3 октября 1990 г. объединение Германии было осуществлено в рамках Основного закона. Политические дебаты между левыми политическими силами и христианскими демократами касались, прежде всего, вопроса о том, на основании какой именно правовой формулы будет реализовано «вступление» ГДР в ФРГ (по ст. 146, предусматривающей принятие новой конституции или и по ст. 23 , на основании которой этот процесс мог быть реализован без разработки нового текста, но поправками)). В Японии же заимствование институтов шло директивным характером: конституция была разработана и навязана извне оккупационными властями [18]. Хотя при этом, несмотря на разрыв правовой преемственности (как и в случае с основным законом ФРГ), японская конституция была принята как поправка к действовавшей конституции Мейдзи, что лишь в некоторой степени было призвано легитимировать сам способ «имплантации» новых политических институтов. Стоит отметить, что в отличие от Германии в Японии не сложилось консенсуса в отношении конституции: есть те, кто ее защищает (социал-демократы), а также те, кто ее критикует, предлагая поправки и указывая на то, что она навязана стране оккупационным режимом. На основании сравнительного анализа опыта конституционного строительства в Японии и Германии российский исследователь А.Н. Медушевский делает вывод о том, что, несмотря на противоречия и трудности в процессе адаптации привнесенных извне моделей к социальной реальности, «представление о невозможности реализации национальных конституционных моделей в иной культурной среде» вполне опровержимо [35]. Исходя из такого теоретического посыла, можно рассматривать «трансплантацию» политических и правовых институтов западных обществ в России как вполне закономерный и, возможно, научно обоснованный процесс. В данном случае основанием для этого выступает достаточно эффективная и долговременная работа «имплантированных институтов» в государствах-реципиентах.

В научной литературе представлено и иное мнение, которое опирается на исследование феномена рецепции западного права в России. Так, в работах С.В. Ткаченко прослеживается стремление оценивать рецепцию правовых институтов как один из способов борьбы с цивилизационной идентичностью России, уничтожением ее правовой ментальности. Автор считает, что идейной основой для такой разрушительной стратегии является миф о «правовом нигилизме» русского народа, который сводится к утверждению о том, что «российский народ неспособен не только к праву, но и к какой-либо самостоятельности» [45]. Такой подход дает возможность автору оценивать происходящие институциональные правовые и политические нововведения как способ ведения информационной войны против России. Поддержку мифа о «правовом нигилизме» оказывает научная и культурная интеллигенция, изначально пренебрежительно настроенная к «нецивилизованному российскому народу».

Такой ракурс, на наш взгляд, совсем не нов. В российской политической мысли есть немало примеров негативного оценивания роли интеллигенции в процессах модернизации. Со времен «Вех» и по наши дни активно продолжается изучение этой роли, и споры ученых зачастую не выходят за пределы традиционных русских вопросов. Книга С.В. Ткаченко интересна прежде всего с позиции оценки идеологического компонента рецепции, что выделяет ее из ряда других работ. Автор последовательно развивает тезис, согласно которому рецепция западного права в современной Рос- 
сии является системой целенаправленных усилий политической элиты с целью интеграции в так называемое «европейское политическое и правовое пространство». Среди выводов в другой книге С.В. Ткаченко можно увидеть четкое определение цели рецепции правовых институтов - это экспансия (открытая или закамуфлированная) донора, которая выражается в навязывании правовой идеологии [46]. Позиция «донора»в таком процессе всегда корыстна, несмотря на декларируемые лозунги о добровольной безвозмездной помощи в модернизации отечественной правовой системы. На первый план в такой стратегии выходят вывоз природных ресурсов, эксплуатация рабочей силы реципиента, тотальный контроль за его действиями. Проводником идей донора является так называемая «пятая колонна», которая определяется как «круг высших сановников страны, озабоченных модернизацией государства и взявших на себя ответственность за ее проведение». Кроме того, автор включает в «пятую колонну» и большинство российских ученых-гуманитариев, «открыто отрицающих самобытность российской нации и поддерживающих правовые реформы правящей политической элиты» [46].

На наш взгляд, в этой позиции прослеживается определенное упрощение и схематизация процесса рецепции политических и правовых институтов. В самом процессе рецепции видится лишь угроза национальной безопасности, суверенитету страны и др. Однако стоит вести речь и об определенных позитивных последствиях рецепции (в том числе тех, которые не планировались субъектами процесса институционального переноса). Возможен также и такой относительно нейтральный исход процесса рецепции, при котором распространяются симулятивные или имитационные практики, не отражающие изначального потенциала того или иного института, но играющие серьезную стабилизирующую роль в обществе. Дело в том, что в современном мире действительно используются технологии, позволяющие одним сильным государствам воздействовать на другие, слабые не через прямое насилие или открытое противодействие, а по-другому. Такое воздействие неизбежно осуществляется в интересах тех, кто способен достигать решающего превосходства в ресурсах и, как правило, ориентировано на закрепление достигнутого status quo или расширение влияния. Кроме того, стоит помнить также и о факторе демонстрационного эффекта современных демократических государств, которые достигли серьезных результатов в своем экономическом развитии, совершенствовании политических институтов, повышении уровня человеческого потенциала (в данном случае речь идет об успехах в образовании, здравоохранении, социальной политике). Таким образом, существуют пусть не всеми разделяемые, но вполне наглядные и стимулирующие рецепции результаты, которые являются одновременно и «образцом» и «соблазном» для правящего класса и населения незападных обществ. Воодушевленные определенной информационной подготовкой социальные массы могут поддержать инициативы правящего класса по реализации самых широких нововведений даже в том случае, когда они могут серьезно ослабить существующие социальные институты и подорвать доверие к власти.

Речь идет, прежде всего, о феномене «мягкой силы». В широкий политический дискурс данное понятие введено Джозефом С. Наем-младшим, американским политологом, профессором Публичной административной школы им. Кеннеди в Гарвардском университете, разработавшим теорию комплексной взаимозависимости. В своей ранней работе Дж. Най высказывал идею о превосходстве США как по показателям военной силы и экономического могущества, так и по параметрам несилового влияния на международные отношения. Последние он и назвал «мягкой мощью» (или «мягкой силой», как не вполне точно переводят это словосочетание некоторые специалисты) [17]. Автор дискутировал со своими коллегами, представителями школы «политического реализма», которым, по его мнению, стоило отказаться от абсолютизации значения «жесткой мощи» (hard power) в мировой политике в условиях совершенно очевидного в конце 80-х гг. прошлого века ослабления биполярной конфронтации. Более поздняя работа Дж. Ная посвящена критике зачастую односторонних, прямых и неэффективных внешнеполитических действий администрации Дж. Буша-младшего, содержание понятия «мощь» (power) автор сравнивает с погодой, от которой зависит все, но влияние которой не всегда поддается рациональному объяснению или математическому исчислению. В целом имеются в виду те инструменты и ресурсы, которые позволяют участникам международных отношений добиваться поставленных целей. Если к hard power относится то, что традиционно считается силовым ресурсом государства - военная и экономическая мощь, то soft power характеризуется тремя основными компонентами: во-первых, культурой (определяемой как набор значимых для общества ценностей, не сводимый к массовой культуре - продукции Голливуда и фаст-фуду); во-вторых, политической идеологией; в-третьих, внешней политикой (понимаемой как дипломатия в широком смысле слова).

И тот и другой вид мощи характеризуют способность государства или другого субъекта международных отношений достигать поставленной 
цели через воздействие на поведение других акторов. Однако разница между ними заключается в том, что используются разные инструменты. Принуждение или навязывание своей воли через угрозы силой или жесткие экономические санкции могут серьезно осложнить отношения между акторами или стать угрозой глобальной безопасности. В то время как воздействие «мягкой» или «гибкой» мощи может формировать механизмы согласования и вовлечения в сотрудничество более широкого характера на базе единых ценностей, благоприятствующих такому сотрудничеству. Исследователи отмечают, что одной из самых важных характеристик «мягкой мощи» является ее относительная независимость от государства и правительства этой мощью обладающих. Власти тяжелее и затратнее манипулировать военной силой или экономическими ресурсами. Действия же в рамках «мягкой мощи» более аморфны, и государствам их труднее точно планировать [47]. Есть еще одно обстоятельство, ограничивающее использование soft power - это уровень социально-экономического развития общества и его восприимчивость к происходящим в мире событиям. Последнее означает не только информационную открытость и возможность граждан свободно получать сведения о событиях в мире и оценках своей собственной страны за рубежом, но также и определенный уровень образования и развития культуры общества. Выраженный интерес к зарубежным моделям институционального устройства может быть ограничен пониманием ценности своей собственной институциональной традиции, что может сдерживать или даже блокировать разнообразные импульсы к «трансплантации». Такой подход демонстрирует современный Китай, культивируя капиталистический уклад в экономике и сохраняя политическую форму социалистического государства демократической диктатуры народа (в соответствии с Конституцией КНР декабря 1982). Российский же опыт в сфере институционального строительства последних двух десятилетий свидетельствует о другом - широкое заимствование западных политических, правовых и экономических институтов шло через серьезные изменения Конституции (период 1990-1993 гг.) и полный отказ от советской идеологии (и даже конституционного ограничения на введение государственной идеологии в ст. 13 Конституции РФ). Стоит отметить, что аналогичную траекторию политической трансформации пережили и многие постсоветские государства. По мнению Н.А. Филипповой, формирование постсоветских государств во многом осуществлялось в русле рецепции европейского права, но характер последующих конституционных реформ в ряде государств продемонстрировал имитационную при- роду такого заимствования, так как учреждение новых институтов не имело системного характера, их место и функции в системе государственной власти не соответствовали конституционным традициям развитых правовых государств [48, С. 37].

Несмотря на разный опыт институционального заимствования (Китай предпочитает использовать достижения капиталистической экономики, сохраняя идеологическую преемственность с коммунистическим режимом, а Россия пережила идеологический разрыв и нарушение правовой преемственности с предыдущим периодом), оба государства рассматриваются на Западе как возможные сильные конкуренты для либеральных демократических режимов. Весьма характерны оценки тех политологов, которые склонны видеть настоящую угрозу в сближении позиций России и КНР. Так, например, известный французский эссеист, автор книг «Большой китайский блеф» (Le grand bluff chinois), и «КГБ во власти» (Le KGB au pouvoir) [27] пишет, что возможная конвергенция «политико-экономических систем самой густонаселенной страны мира и самой большой страны нашей планеты не должна оставлять нас равнодушными. Комплементарные потребности - России нужна рабочая сила, а Китаю - сырье - подталкивают эти страны к сближению, как и общие политические интересы. Люди, стоящие у власти в Кремле, хотят взять исторический реванш над западными странами, на которых они возлагают вину за крах коммунизма и последовавшую за ним дискредитацию страны; а владыки Запретного города, со своей стороны, больше всего боятся малейшего прорыва демократии, который может расшатать фундамент их власти. Ось Москва-Пекин пока еще реальностью не стала, но обе столицы надеются, что это произойдет»[28].

В какой-то мере такая оценка возможной геополитической стратегии крупнейших мировых государств является провоцирующей дискуссию с проекцией на какие-то отдельные важные вопросы современных международных отношений (обеспечение безопасности и стабильности, поддержание режима нераспространения ядерного оружия или др.). На наш взгляд, важнее другое - для какой-то части европейского истеблишмента демократическая Россия, развивающаяся в совершенно новых условиях, использующая демократические институты и современные политические практики согласования интересов (пусть даже в не самом совершенном виде), остается опасным противником. Об этом свидетельствуют публикации, в которых современный политический режим в нашей стране жестко и последовательно критикуется, зачастую с оценками, которые выходят далеко за пределы научного анализа $[2,10,11,13,14,15,16,20,25]$. Общий вектор 
таких публикаций - констатация угроз, исходящих от «недемократической» России в силу склонности российской власти к агрессии и экспансии.

Таким образом, на становление и развитие новых политических институтов в стране большое влияние оказывает не только политическая традиция, исторический опыт и траектория предшествующего развития общества, но и демонстрация успеха иных обществ и политических систем, добившихся значительных результатов в ходе модернизации. Такое воздействие очень непросто оценить, но, в то же время, невозможно отрицать его значение для правящих элит в современных условиях повышения роли массовых коммуникаций и возможностей проецирования и распространения «передового» управленческого и политического опыта.

\section{Библиография:}

1. Arato A. The New Democracies and American Constitutional Design // Constellations. 2000. September. Vol. 7. P. 316-340.

2. Buhbe M., Gorzka G. Russland heute. Rezentralisierung des Staates unter Putin. Wiesbaden, VS Verlag für Sozialwissenschaften, 2007;

3. Carothers Th. U.S. Democracy Promotion During and After Bush / Carnegie Endowment for International Peace. Washington, 2007.

4. $\quad$ Counterinsurgency and constitutional design // Harvard Law Review. 2008. Vol. 121. P. 1622-1643.

5. Diamond L. Building Democracy After Conflict: Lessons from Iraq // Journal of Democracy. 2005. January. Vol. 16. P. 9-23.

6. Diamond L. Promoting Democracy in Post-Conflict and Failed States: Lessons and Challenges // Taiwan Journal of Democracy. 2006. Vol. 2. № 2. P. 93-116.

7. Dobbins J. et al. America's Role in Nation-Building: From Germany to Iraq. Santa Monica: RAND, 2003.

8. Dobbins J., Jones S.G., Crane K., Degrasse B.C. The beginner's guide to nation-building. Santa Monica: RAND, National Security Research Division, 2007.

9. Elster J., Offe C., Preuss U. Institutional Design in Post-Communist Societies: Rebuilding the Ship at Sea / Ed. by R E. Goodin. Theories of Institutional Design. Cambridge: Cambridge University Press, 1998.

10. Goldfarb A., Litwinenko M. Tod eines Dissidenten. Warum Alexander Litwinenko sterben musste. Hamburg: Hoffmann und Campe Verlag, 2007;

11. Goldman M.I., MyerJ.J. Petrostate: Putin, Power and the New Russia. Oxford University Press, 2008;

12. Grimm D. Constitutional Reform in Germany after the Revolution of 1989 // Constitutional Policy and Change in Europe / Ed. by J.J. Hesse, N. Johnson. Oxford: Oxford Univ. Press, 1995. P. 129-151.

13. Haug R. Die Kreml AG. Putin, Russland und die Deutschen. Stuttgart: Hohenheim Verlag, 2007;

14. Levine Steve Putin's Labyrinth: Spies, Murder, and the Dark Heart of the New Russia. Random House Trade Paperbacks, 2009;

15. Lucas Ed. Der Kalte Krieg des Kreml. Wie das Putin-System Russland und den Westen bedroht. München: Riemann Verlag, 2008.

16. Mommsen M., Nußberger A. Das System Putin. Gelenkte Demokratie und politische Justiz in Russland. München: C. H. Beck Verlag, 2007;

17. Nye J.S. Jr. Bound to lead: the changing nature of American power. N. - Y.: Basic Books, 1990.

18. Ordeshook P. Constitutions for new democracies: Reflections of turmoil or agents of stability? // Public Choice. 1997. № 90. P. 55-72.

19. Otake H. Two Contrasting Constitutions in the Postwar World: The Making of the Japanese and the West German Constitutions // Five Decades of Constitutionalism in Japanese Society / Ed. by Y. Higuchi. Tokyo: Tokyo Univ. Press, 2000.

20. Reitschuster B. Putins Demokratur. Wie der Kreml den Westen das Fürchten lehrt. Berlin: Econ Verlag, 2006;

21. Reynolds A. Constitutional Medicine // Journal of Democracy. 2005. January. Vol. 16. № 1. P. 54-68.

22. Samuels K. Post-Conflict Peace-Building and Constitution-Making // Chicago Journal of International Law. 2006. Winter. Vol. 6. №. 2. P. 1-19.

23. Samuels K. State-building and Constitutional Design after Conflict // IPA REPORT. 2006. June. 23 р. [Электронный реcypc]. URL: http://www.odi.org.uk/events/states_06/-18thmay/presentations/20samuels.pdf.

24. The Theory and Practice of Institutional Transplantation: Experiencies with the Transfer of Policy Institutions / Ed. by M. de Jong, K. Lalenis and V. Mammadouh. Kluwer Academic Publishers, 2002. P. 283.

25. Wegren St. K. (Ed.). Herspring D.R. (Ed.) After Putin's Russia: Past Imperfect, Future Uncertain. 4 ed. Rowman \& Littlefield Publishers, Inc., 2009.

26. Вельцель К., Ингелхарт Р. Как развитие ведет к демократии // Россия в глобальной политике. 2009. Май-июнь. № 3.

27. Вольтон Т. КГБ во Франции. М.: Центрполиграф, 2000.

28. Вольтон Т. Чтобы понять, куда идет Россия, посмотрите на Китай. [Электронный pecypc]. URL: http://www.inosmi. ru/world/20080107/238761.html. (перевод из «Le Figaro», Франция).

29. Ворожейкина Т.Е. Авторитарные режимы XX века и современная Россия: сходства и отличия // Тез. выступ. на конф. «Российские альтернативы». (Пятые Ходорковские чтения). 8 декабря 2009 г. [Электронный ресypc]. URL: http://www.memo.ru/-2009/12/12/vorozheykina.htm.

30. Гарр Т.Г. Почему люди бунтуют. СПб., 2005. С.147.

31. Колеров М. Комикс о «Невоюющих демократиях» // Там же. Русский журнал - Тема недели. 2009. Сентябрь. № 21. C. 17.

32. Кулагин В.М. Международная безопасность. М.: Аспект-Пресс, 2006;

33. Кулагин B.M. Мир в XXI веке: многополюсный баланс сил или глобальный Pax Democratica? Гипотеза «демократического мира» в контексте альтернатив мирового развития // Полис. 2000. № 1; 
34. Лафитский В.И. Механизмы воздействия процессов глобализации на конституционный строй // Реализация Конституции: от идей к практике развития конституционного строя (состояние и перспективы российского конституционализма на общемировом фоне). Международное исследование. // Конституционный вестник. 2008. № 1(19). С. 311.

35. Медушевский А.Н. Экспорт конституционализма: американская модель в Японии и Германии // Космополис. 2006. Весна. № 1(15). С. 146.

36. Нуреев Р.М., Латов Ю.В. Карл Поланьи - наш современник // «Великая трансформация» Карла Поланьи: прошлое, настоящее, будущее / Под общ. ред. проф. Р.М. Нуреева. М.: Изд. дом ГУ ВШЭ, 2006. С. 11.

37. Общая и прикладная политология: Учеб. пособие / Под общ. ред. В.И. Жукова, Б.И. Краснова. М.: МГСУ; Изд-во «Союз», 1997. С. 530.

38. Олейник А.Н. Институциональная экономика. М., 2000. С. 202-204.

39. Оффе К. Дилемма одновременности: демократизация и рыночная экономика в Восточной Европе // Повороты истории: Постсоциалистические трансформации глазами немецких исследователей Т. 2: Постсоциалистические трансформации в сравнительной перспективе. СПб., М., Берлин, 2003. С. 11.

40. Петручак Л.А. Проблемы возникновения, развития и формирования правил оценки доказательств в уголовном судопроизводстве России: Историко-правовой аспект: Автореф. дис. ... канд. юрид. наук. Ставрополь, 2000. С. 6.

41. Райзберг Б.А., Лозовский Л.Ш., Стародубцева Е.Б. Современный экономический словарь. 5-е изд., перераб. и доп. М., 2007.

42. Сингер Д. Дж. Нормы здорового общества - вот необходимые стандарты //

43. Соловьев А.И. Институциональный дизайн российской власти: исторический ремейк или матрица развития?// Общественные науки и современность. 2004. №1. С. 64-76.

44. Соловьев А.И. Causae и каверзы политической демократии.// Общественные науки и современность. 1998. №6. C. 71-84;

45. Ткаченко С.В. Правовые реформы в России: проблемы рецепции западного права. Самара, 2007. С. 363.

46. Ткаченко С.В. Рецепция западного права в России: проблемы взаимодействия субъектов. Самара, 2009. С. 5.

47. Трибрат В. «Мягкая безопасность» по Джозефу Наю // Международные процессы. 2005. Январь-апрель. Т. 3, № 1 (7).

48. Филиппова Н.А. Бикамерализм в постсоветских государствах: тенденции развития института // Политэкс: политическая экспертиза: альманах. Вып. 3. СПб., 2005. С. 37.

49. Ц Цыганков П.А. Теория международных отношения. М., 2003;

50. Цыганков П.А. Цыганков А.П. Социология международных отношений. М., 2006.

51. Цыганков П.А., Цыганков А.П. Кризис идеи «демократического мира».// Международные процессы. 2005 Том 3. № 3(9). Сентябрь-декабрь.

52. Манойло А.В. Геополитическая картина современного мира и управляемый хаос // Мировая политика. - 2015. 1. - C. 66 - 80. DOI: 10.7256/2409-8671.2015.1.12665. URL: http://www.e-notabene.ru/wi/article_12665.html

53. Карпович О.Г. Международные организации и их роль в предупреждении, урегулировании и разрешении этнополитических конфликтов // Национальная безопасность / nota bene. - 2014. - 3. - С. 398 - 405. DOI: 10.7256/20738560.2014.3.11786.

54. Вепринцев В.Б. Влияние информационной составляющей на взаимодействие геополитических субъектов // Мировая политика. - 2015. - 1. - С. 192 - 212. DOI: 10.7256/2409-8671.2015.1.12621. URL: http://www.e-notabene.ru/ wi/article_12621.html

55. Галвес Деролле П. Brazil - New Age // Конфликтология / nota bene. - 2014. - 1. - C. 136 - 139. DOI: $10.7256 / .2014 .1 .13181$.

56. Калачев Д.Н. Основные направления сотрудничества России и НАТО // Тренды и управление. - 2015. - 1. - С. 36 43. DOI: $10.7256 / 2307-9118.2015 .1 .13712$.

57. Буневич Д.С. Крымский кризис 2014 года и создание новой архитектуры международных отношений // Конфликтология / nota bene. - 2015. - 2. - C. 133 - 139. DOI: 10.7256/2409-8965.2015.2.14333.

58. Филиппов В.Р. Территориальные конфликты и перспектива изменения границ на африканском континенте // Конфликтология / nota bene. - 2014. - 1. - C. 28 - 39. DOI: 10.7256/.2014.1.13041.

59. Виноградова Е.А. Роль публичной дипломатии АЛБА в урегулировании сирийского конфликта // Мировая политика. - 2015. - 1. - С. 55 - 65. DOI: 10.7256/2409-8671.2015.1.12619. URL: http://www.e-notabene.ru/wi/ article_12619.html

60. Бородинов Е.Н. Анализ крымской внешнеполитической операции // Мировая политика. - 2015. - 1. - С. 81 - 88. DOI: 10.7256/2409-8671.2015.1.12586. URL: http://www.e-notabene.ru/wi/article_12586.html

61. Вепринцев В.Б. Влияние информационной составляющей на взаимодействие геополитических субъектов // Мировая политика. - 2015. - 1. - C. 192 - 212. DOI: 10.7256/2409-8671.2015.1.12621. URL: http://www.e-notabene.ru/ wi/article_12621.html

\section{References (transliterated):}

1. Arato A. The New Democracies and American Constitutional Design // Constellations. 2000. September. Vol. 7. P. 316-340.

2. Buhbe M., Gorzka G. Russland heute. Rezentralisierung des Staates unter Putin. Wiesbaden, VS Verlag für Sozialwissenschaften, 2007;

3. Carothers Th. U.S. Democracy Promotion During and After Bush / Carnegie Endowment for International Peace. Washington, 2007.

4. $\quad$ Counterinsurgency and constitutional design // Harvard Law Review. 2008. Vol. 121. P. 1622-1643.

5. Diamond L. Building Democracy After Conflict: Lessons from Iraq // Journal of Democracy. 2005. January. Vol. 16. P. 9-23.

6. Diamond L. Promoting Democracy in Post-Conflict and Failed States: Lessons and Challenges // Taiwan Journal of Democracy. 2006. Vol. 2. № 2. P. 93-116. 
7. Dobbins J. et al. America's Role in Nation-Building: From Germany to Iraq. Santa Monica: RAND, 2003.

8. Dobbins J., Jones S.G., Srane K., Degrasse B.C. The beginner's guide to nation-building. Santa Monica: RAND, National Security Research Division, 2007.

9. Elster J., Offe C., Preuss U. Institutional Design in Post-Communist Societies: Rebuilding the Ship at Sea / Ed. by R E. Goodin. Theories of Institutional Design. Cambridge: Cambridge University Press, 1998.

10. Goldfarb A., Litwinenko M. Tod eines Dissidenten. Warum Alexander Litwinenko sterben musste. Hamburg: Hoffmann und Campe Verlag, 2007;

11. Goldman M.I., MyerJ.J. Petrostate: Putin, Power and the New Russia. Oxford University Press, 2008;

12. Grimm D. Constitutional Reform in Germany after the Revolution of 1989 // Constitutional Policy and Change in Europe / Ed. by J.J. Hesse, N. Johnson. Oxford: Oxford Univ. Press, 1995. P. 129-151.

13. Haug R. Die Kreml AG. Putin, Russland und die Deutschen. Stuttgart: Hohenheim Verlag, 2007;

14. Levine Steve Putin's Labyrinth: Spies, Murder, and the Dark Heart of the New Russia. Random House Trade Paperbacks, 2009;

15. Lucas Ed. Der Kalte Krieg des Kreml. Wie das Putin-System Russland und den Westen bedroht. München: Riemann Verlag, 2008.

16. Mommsen M., Nußberger A. Das System Putin. Gelenkte Demokratie und politische Justiz in Russland. München: C. H. Beck Verlag, 2007;

17. Nye J.S. Jr. Bound to lead: the changing nature of American power. N. - Y.: Basic Books, 1990.

18. Ordeshook P. Constitutions for new democracies: Reflections of turmoil or agents of stability? // Public Choice. 1997. № 90. P. 55-72.

19. Otake H. Two Contrasting Constitutions in the Postwar World: The Making of the Japanese and the West German Constitutions // Five Decades of Constitutionalism in Japanese Society / Ed. by Y. Higuchi. Tokyo: Tokyo Univ. Press, 2000.

20. Reitschuster B. Putins Demokratur. Wie der Kreml den Westen das Fürchten lehrt. Berlin: Econ Verlag, 2006;

21. Reynolds A. Constitutional Medicine // Journal of Democracy. 2005. January. Vol. 16. № 1. P. 54-68.

22. Samuels K. Post-Conflict Peace-Building and Constitution-Making // Chicago Journal of International Law. 2006. Winter. Vol. 6. №. 2. P. 1-19.

23. Samuels K. State-building and Constitutional Design after Conflict // IPA REPORT. 2006. June. 23 p. [Elektronnyi resurs]. URL: http://www.odi.org.uk/events/states_06/-18thmay/presentations/20samuels.pdf.

24. The Theory and Practice of Institutional Transplantation: Experiencies with the Transfer of Policy Institutions / Ed. by M. de Jong, K. Lalenis and V. Mammadouh. Kluwer Academic Publishers, 2002. P. 283.

25. Wegren St. K. (Ed.). Herspring D.R. (Ed.) After Putin's Russia: Past Imperfect, Future Uncertain. 4 ed. Rowman \& Littlefield Publishers, Inc., 2009.

26. Vel'tsel' K., Ingelkhart R. Kak razvitie vedet k demokratii // Rossiya v global'noi politike. 2009. Mai-iyun'. № 3.

27. Vol'ton T. KGB vo Frantsii. M.: Tsentrpoligraf, 2000.

28. Vol'ton T. Chtoby ponyat', kuda idet Rossiya, posmotrite na Kitai. [Elektronnyi resurs]. URL: http://www.inosmi.ru/ world/20080107/238761.html. (perevod iz «Le Figaro», Frantsiya).

29. Vorozheikina T.E. Avtoritarnye rezhimy KhKh veka i sovremennaya Rossiya: skhodstva i otlichiya // Tez. vystup. na konf. «Rossiiskie al'ternativy». (Pyatye Khodorkovskie chteniya). 8 dekabrya 2009 g. [Elektronnyi resurs]. URL: http://www. memo.ru/-2009/12/12/vorozheykina.htm.

30. Garr T.G. Pochemu lyudi buntuyut. SPb., 2005. S.147.

31. Kolerov M. Komiks o «Nevoyuyushchikh demokratiyakh» // Tam zhe. Russkii zhurnal - Tema nedeli. 2009. Sentyabr'. № 21. S. 17.

32. Kulagin V.M. Mezhdunarodnaya bezopasnost'. M.: Aspekt-Press, 2006;

33. Kulagin V.M. Mir v XXI veke: mnogopolyusnyi balans sil ili global'nyi Pax Democratica? Gipoteza «demokraticheskogo mira» v kontekste al'ternativ mirovogo razvitiya // Polis. 2000. № 1;

34. Lafitskii V.I. Mekhanizmy vozdeistviya protsessov globalizatsii na konstitutsionnyi stroi // Realizatsiya Konstitutsii: ot idei k praktike razvitiya konstitutsionnogo stroya (sostoyanie i perspektivy rossiiskogo konstitutsionalizma na obshchemirovom fone). Mezhdunarodnoe issledovanie. // Konstitutsionnyi vestnik. 2008. № 1(19). S. 311.

35. Medushevskii A.N. Eksport konstitutsionalizma: amerikanskaya model' v Yaponii i Germanii // Kosmopolis. 2006. Vesna. № 1(15). S. 146.

36. Nureev R.M., Latov Yu.V. Karl Polan'i - nash sovremennik // «Velikaya transformatsiya» Karla Polan'i: proshloe, nastoyashchee, budushchee / Pod obshch. red. prof. R.M. Nureeva. M.: Izd. dom GU VShE, 2006. S. 11.

37. Obshchaya i prikladnaya politologiya: Ucheb. posobie / Pod obshch. red. V.I. Zhukova, B.I. Krasnova. M.: MGSU; Izd-vo «Soyuz», 1997. S. 530.

38. Oleinik A.N. Institutsional'naya ekonomika. M., 2000. S. 202-204.

39. Offe K. Dilemma odnovremennosti: demokratizatsiya i rynochnaya ekonomika v Vostochnoi Evrope // Povoroty istorii: Postsotsialisticheskie transformatsii glazami nemetskikh issledovatelei T. 2: Postsotsialisticheskie transformatsii $\mathrm{v}$ sravnitel'noi perspektive. SPb., M., Berlin, 2003. S. 11.

40. Petruchak L.A. Problemy vozniknoveniya, razvitiya i formirovaniya pravil otsenki dokazatel'stv v ugolovnom sudoproizvodstve Rossii: Istoriko-pravovoi aspekt: Avtoref. dis. ... kand. yurid. nauk. Stavropol', 2000. S. 6.

41. Raizberg B.A., Lozovskii L.Sh., Starodubtseva E.B. Sovremennyi ekonomicheskii slovar'. 5-e izd., pererab. i dop. M., 2007.

42. Singer D. Dzh. Normy zdorovogo obshchestva - vot neobkhodimye standarty //

43. Solov'ev A.I. Institutsional'nyi dizain rossiiskoi vlasti: istoricheskii remeik ili matritsa razvitiya?// Obshchestvennye nauki i sovremennost'. 2004. №1. S. 64-76.

44. Solov’ev A.I. Causae i kaverzy politicheskoi demokratii.// Obshchestvennye nauki i sovremennost'. 1998. №6. S. 71-84;

45. Tkachenko S.V. Pravovye reformy v Rossii: problemy retseptsii zapadnogo prava. Samara, 2007. S. 363.

46. Tkachenko S.V. Retseptsiya zapadnogo prava v Rossii: problemy vzaimodeistviya sub"ektov. Samara, 2009. S. 5.

47. Tribrat V. «Myagkaya bezopasnost’» po Dzhozefu Nayu // Mezhdunarodnye protsessy. 2005. Yanvar'-aprel'. T. 3, № 1 (7). 
48. Filippova N.A. Bikameralizm v postsovetskikh gosudarstvakh: tendentsii razvitiya instituta // Politeks: politicheskaya ekspertiza: al'manakh. Vyp. 3. SPb., 2005. S. 37.

49. Tsygankov P.A. Teoriya mezhdunarodnykh otnosheniya. M., 2003;

50. Tsygankov P.A. Tsygankov A.P. Sotsiologiya mezhdunarodnykh otnoshenii. M., 2006.

51. Tsygankov P.A., Tsygankov A.P. Krizis idei «demokraticheskogo mira».// Mezhdunarodnye protsessy. 2005 Tom 3. № 3(9). Sentyabr'-dekabr'.

52. Manoilo A.V. Geopoliticheskaya kartina sovremennogo mira i upravlyaemyi khaos // Mirovaya politika. - 2015. - 1. C. 66 - 80. DOI: 10.7256/2409-8671.2015.1.12665. URL: http://www.e-notabene.ru/wi/article_12665.html

53. Karpovich O.G. Mezhdunarodnye organizatsii i ikh rol' v preduprezhdenii, uregulirovanii i razreshenii etnopoliticheskikh konfliktov // Natsional'naya bezopasnost' / nota bene. - 2014. - 3. - C. 398 - 405. DOI: 10.7256/2073-8560.2014.3.11786.

54. Veprintsev V.B. Vliyanie informatsionnoi sostavlyayushchei na vzaimodeistvie geopoliticheskikh sub"ektov // Mirovaya politika. - 2015. - 1. - C. 192 - 212. DOI: 10.7256/2409-8671.2015.1.12621. URL: http://www.e-notabene.ru/wi/ article_12621.html

55. Galves Derolle P. Brazil - New Age // Konfliktologiya / nota bene. - 2014. - 1. - C. 136 - 139. D0I: 10.7256/.2014.1.13181.

56. Kalachev D.N. Osnovnye napravleniya sotrudnichestva Rossii i NATO // Trendy i upravlenie. - 2015. - 1. - C. 36 - 43. DOI: 10.7256/2307-9118.2015.1.13712.

57. Bunevich D.S. Krymskii krizis 2014 goda i sozdanie novoi arkhitektury mezhdunarodnykh otnoshenii // Konfliktologiya / nota bene. - 2015. - 2. - C. 133 - 139. DOI: 10.7256/2409-8965.2015.2.14333.

58. Filippov V.R. Territorial'nye konflikty i perspektiva izmeneniya granits na afrikanskom kontinente // Konfliktologiya / nota bene. - 2014. - 1. - C. 28 - 39. DOI: 10.7256/.2014.1.13041.

59. Vinogradova E.A. Rol' publichnoi diplomatii ALBA v uregulirovanii siriiskogo konflikta // Mirovaya politika. - 2015. - 1. C. 55 - 65. DOI: 10.7256/2409-8671.2015.1.12619. URL: http://www.e-notabene.ru/wi/article_12619.html

60. Borodinov E.N. Analiz krymskoi vneshnepoliticheskoi operatsii // Mirovaya politika. - 2015. - 1. - C. 81 - 88. DOI: 10.7256/2409-8671.2015.1.12586. URL: http://www.e-notabene.ru/wi/article_12586.html

61. Veprintsev V.B. Vliyanie informatsionnoi sostavlyayushchei na vzaimodeistvie geopoliticheskikh sub"ektov // Mirovaya politika. - 2015. - 1. - C. 192 - 212. DOI: 10.7256/2409-8671.2015.1.12621. URL: http://www.e-notabene.ru/wi/ article_12621.html 